\title{
Most Popular Theories in Information Systems Research
}

\author{
Patricio Ramírez-Correa \\ Catholic University of the North \\ Larrondo 1281 \\ Coquimbo, Chile \\ 56512209899 \\ patricio.ramirez@ucn.cl
}

\begin{abstract}
The objective of this work is to identify the theories most widely applied in information systems research. In order to achieve this purpose, an exploration of literature 2015 is realized, based on cocitation analysis. Results indicate that Dynamic Capabilities Theory appears as main in the discussion of information systems research.
\end{abstract}

\section{Categories and Subject Descriptors}

K.6.m [Management of Computing and Information Systems]: Miscellaneous.

\section{General Terms}

Management, Theory

\section{Keywords}

Co-citation analysis, Theories, Information Systems, Research.

\section{INTRODUCTION}

Information Systems is a new discipline with its own accumulative tradition and history[1]. To progress in the understanding of the information systems, it is necessary to conduct research built on theory. Indeed, information systems have an important tradition of developing and appropriating theories to examine main disciplinary topics [2].

As the discipline matures, total of new articles published every year increases. Consequently, the identification of the most widely used theoretical fundamentals becomes a formidable task for those students interested in the discipline[3].

In this context, the objective of this study is to identify the theories most widely applied in information systems research from the literature of the year 2015 .

The remaining of the paper is organized as follows. Section 2 presents briefly the methodology. Section 3 presents the results. Finally, section 4 discusses the results.

\section{DATA AND METHODOLOGY}

The data collected on citations obtained from the Journal Citation Reports at Thomson-Reuters' Web of Science (formerly ISI Citation Index). In particular, articles from journals of the discipline belong to the category of Web of Science management were considered. These journals were identified using data from the Index of Information Systems Journals [4] as in January 2016. Finally, 3,035 articles published in 2015 in 52 ISI journals were obtained (see annex).

In order to obtain the most relevant authors in the literature 2015, a co-citation analysis was performed. It was used in VOSviewer software for this purpose. VOSviewer has been developed for creating, visualizing, and exploring bibliometric maps of science (see http://www.vosviewer.com/).

A total of 113,426 citations were identified. For analysis with VOSviewer, the authors cited 100 times or more were considered. Within that this list of authors, the authors associated with techniques were eliminated. Finally, each author was associated with a theory, based on the specific articles cited and a literature review [2].

\section{RESULTS}

Below we show the main results of bibliometric analysis of literature. Figure 1 shows the result in relation to journals cited five or more times.

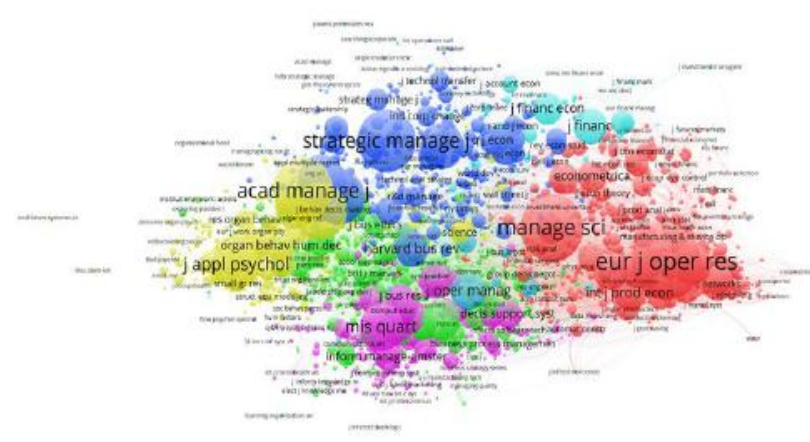

Figure 1. Journals most widely cited
Permission to make digital or hard copies of all or part of this work for personal or classroom use is granted without fee provided that copies are not made or distributed for profit or commercial advantage and that copies bear this notice and the full citation on the first page. To copy otherwise, or republish, to post on servers or to redistribute to lists, requires prior specific permission and/or a fee.

SBSI 2016, May 17-20, 2016, Florianópolis, Santa Catarina, Brazil.

Copyright SBC 2016. 
Figure 2 shows the result in relation to cooperation between authors from different countries.

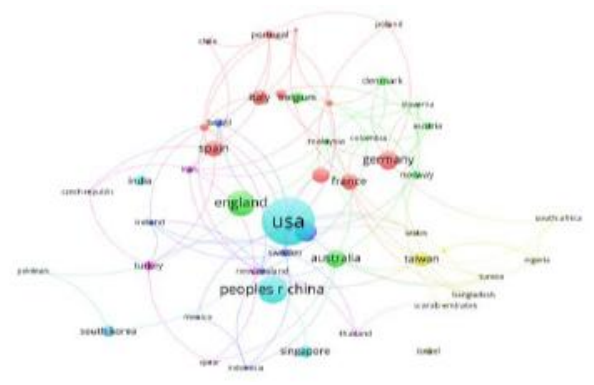

Figure 2. Cooperation between countries

Figure 3 shows the result in relation to cooperation between authors from different institutions.

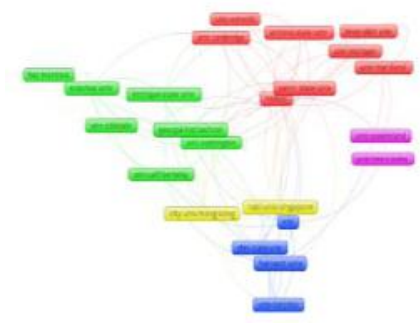

Figure 3. Cooperation between institutions

Figure 4 shows the result of the co-citation analysis. Table 1 shows these authors and theories associated with them.

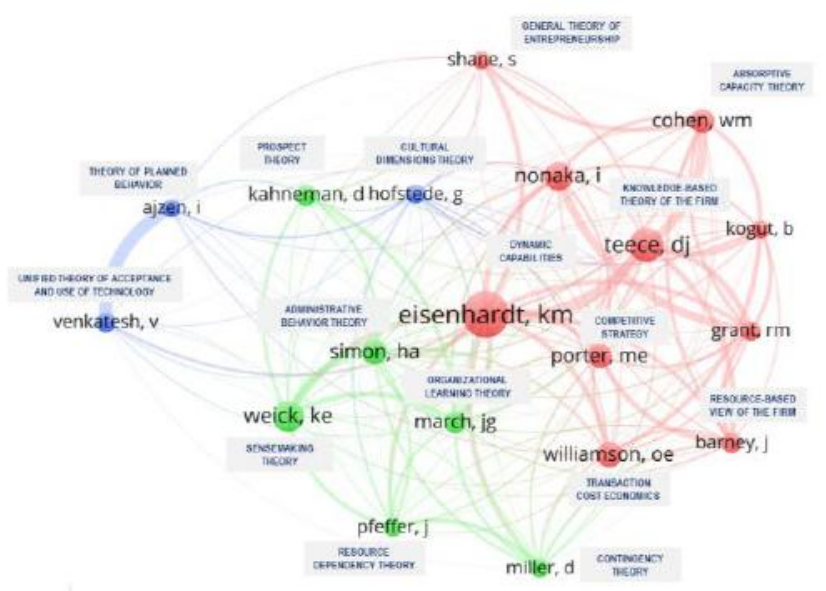

Figure 4. Co-citation analysis

Additionally, as presented in Figure 4 and Table 1, analysis identified three clusters. First cluster (in red) is the largest centre, and it is associated mostly organizational level theories. Second cluster (in green) has a size slightly smaller than the previous one, and it is associated with theories of individual behavior. Third cluster (in blue) is the smallest, and it is associated with theories of acceptance of technologies.
Table 1. Authors and theories

\begin{tabular}{|c|c|c|c|}
\hline Cluster & Theory & Author & Cites \\
\hline \multirow{10}{*}{1} & \multirow[t]{2}{*}{ Dynamic capabilities } & Eisenhardt, KM & 258 \\
\hline & & Teece, DJ & 190 \\
\hline & $\begin{array}{c}\text { Transaction cost } \\
\text { economics }\end{array}$ & Williamson, OE & 144 \\
\hline & $\begin{array}{c}\text { Absorptive capacity } \\
\text { theory }\end{array}$ & Cohen, WM & 137 \\
\hline & Competitive strategy & Porter, ME & 136 \\
\hline & $\begin{array}{l}\text { Resource-based view } \\
\text { of the firm }\end{array}$ & Barney, J & 114 \\
\hline & \multirow{3}{*}{$\begin{array}{l}\text { Knowledge-based } \\
\text { theory of the firm }\end{array}$} & Nonaka, I & 161 \\
\hline & & Grant, RM & 112 \\
\hline & & Kogut, B & 104 \\
\hline & $\begin{array}{l}\text { General theory of } \\
\text { entrepreneurship }\end{array}$ & Shane, $\mathrm{S}$ & 102 \\
\hline \multirow{6}{*}{2} & Sense making theory & Weick, KE & 173 \\
\hline & $\begin{array}{l}\text { Administrative } \\
\text { behavior theory }\end{array}$ & Simon, HA & 138 \\
\hline & $\begin{array}{l}\text { Organizational } \\
\text { learning theory }\end{array}$ & March, JG & 122 \\
\hline & Prospect theory & Kahneman, D & 120 \\
\hline & Contingency theory & Miller, D & 108 \\
\hline & $\begin{array}{c}\text { Resource dependency } \\
\text { theory }\end{array}$ & Pfeffer, J & 101 \\
\hline \multirow{3}{*}{3} & $\begin{array}{c}\text { Unified theory of } \\
\text { acceptance and use of } \\
\text { technology }\end{array}$ & Venkatesh, V & 112 \\
\hline & $\begin{array}{l}\text { Cultural dimensions } \\
\text { theory }\end{array}$ & Hofstede, G & 108 \\
\hline & $\begin{array}{c}\text { Theory of planned } \\
\text { behavior }\end{array}$ & Ajzen, I & 102 \\
\hline
\end{tabular}

\section{DISCUSSION}

This paper presented the initial results of an exploration of the literature of information systems in 2015 , with focus in find the most-used theories.

Three points in relation to the results must highlight. First, Dynamic Capabilities Theory [5] appears as main in the discussion of management information systems. Second, wide used theories associated with the acceptance of technologies (Theory of planned behavior [6] and Unified theory of acceptance and use of technology [7]) appear in the periphery of the central core. Third, the classical theory about the DeLone and McLean Information Systems Success Model [8] not appear in this analysis.

This research will continue to examination the results presented in detail, and in particular, how these findings relate to other studies published in the literature on theories in information systems. 


\section{REFERENCES}

[1] B. Mohanty, "Management Information Systems Quarterly (MISQ): A Bibliometric Study," Library Philosophy and Practice, no. 1, 2014.

[2] Y. K. Dwivedi, M. R. Wade, and S. L. Schneberger, Information Systems Theory: Explaining and Predicting Our Digital Society: Springer Science \& Business Media, 2011.

[3] K. A. Walstrom, and L. N. Leonard, "Citation classics from the information systems literature," Information \& Management, vol. 38, no. 2, pp. 59-72, 2000.

[4] J. Lamp, "The index of information systems journals," 2006.

[5] D. J. Teece, G. Pisano, and A. Shuen, "Dynamic capabilities and strategic management," Strategic management journal, vol. 18, no. 7, pp. 509-533, 1997.

[6] I. Ajzen, and M. Fishbein, "Understanding attitudes and predicting social behaviour," 1980.

[7] V. Venkatesh, M. G. Morris, G. B. Davis, and F. D. Davis, "User acceptance of information technology: Toward a unified view," Mis Quarterly, vol. 27, no. 3, pp. 425-478, Sep, 2003.

[8] W. H. DeLone, and E. R. McLean, "Information systems success: the quest for the dependent variable," Information systems research, vol. 3, no. 1, pp. 60-95, 1992.

\section{ANNEX: JOURNALS LIST}

1. Academy of Management Journal

2. Academy of Management Learning Education

3. Academy of Management Perspectives

4. Academy of Management Review

5. Administrative Science Quarterly

6. Australian Journal of Management

7. Business Process Management Journal

8. California Management Review

9. Decision Analysis

10. Electronic Commerce Research

11. European Journal of Operational Research
12. Group Decision and Negotiation

13. Group Organization Management

14. Harvard Business Review

15. IEEE Transactions on Engineering Management

16. Information and Organization

17. Information Management

18. Information Systems and E Business Management

19. Information Systems Research

20. Information Technology Management

21. Interfaces

22. International Journal of Accounting Information Systems

23. International Journal of Forecasting

24. International Journal of Project Management

25. International Journal of Technology Management

26. Journal of Information Technology

27. Journal of Knowledge Management

28. Journal of Management Information Systems

29. Journal of Operations Management

30. Journal of Organizational and End User Computing

31. Journal of Organizational Behavior

32. Journal of Organizational Change Management

33. Journal of Service Management

34. Journal of Strategic Information Systems

35. Journal of Supply Chain Management

36. Journal of Technology Transfer

37. Journal of the Operational Research Society

38. Knowledge Management Research Practice

39. Management Communication Quarterly

40. Management Science

41. MIT Sloan Management Review

42. New Technology Work and Employment

43. Omega International Journal of Management Science

44. Organizational Behavior and Human Decision Processes

45. Project Management Journal

46. Science Technology and Society

47. Small Group Research

48. Strategic Management Journal

49. Systemic Practice and Action Research

50. Systems Research and Behavioral Science

51. Technovation

52. Total Quality Management Business Excellence 